\title{
光ナノインプリント用 UV 硬化樹脂
}

\section{1. 緒}

\section{言}

ナノインプリントリソグラフィー (Nanoimprint Lithography；NIL）はプリンストン大学の Chou 教授が 1995 年 に提案したリソグラフィー技術であり ${ }^{1)}$ ，近年ナノ微細加 工の有望な手段として注目を集めている. NIL は半導体微 細加工ロードマップにおいて有力な次世代加工技術として 位置づけられているが，リソグラフィー技術の他にナノ構 造の成形技術としての可能性も見込まれ，ストレージメ ディア, バイオ, 光学部材等, さまざまな分野において研 究開発がなされている.

ナノインプリントとは，樹脂をモールド（型）と基板で 挟み込み, ナノパターンを転写する技術である. 光リソグ ラフィーの観点から述べると, 他の半導体微細加工技術と 比較してステッパーや電子線描画装置といった高額な装置 を必要とせず，プロセスが単純であることから低コストか つ量産プロセスへの適用性が高いという利点を有する.

ナノインプリントにも様々な種類があるが，主に熱ナノ インプリントと光 (UV) ナノインプリントの 2 種類に大 別できる. 両者の材料面での違いを述べると, 熱ナノイン プリントでは加熱により軟化する樹脂（またはガラス等の 無機物）を，UVナノインプリント（以下，UV-NIL）で は光硬化性の液状樹脂を用いる点が異なる．熱ナノインプ リントと比較して，UV-NIL では加熱/冷却サイクルが不 要なため樹脂やモールドの熱膨張・収縮等の変形が発生せ ず，スループットや解像度，アライメント精度などの点で 優れているといわれている．材料の選択幅が広く光源も不 要であるため当初は熱ナノインプリントの研究が先行して いたが，ここ数年の間にUV-NIL の研究レベルは熱ナノ インプリントを凌ぐ勢いとなっている，本稿では UV-NIL 用樹脂の材料設計から評価方法, 並びに UV-NIL プロセ スを用いた加工例についても紹介する.

UV-NIL プロセスを図 1 に示す. (1)シリコンウェハー, 石英，ガラス，フィルム等の基板上に液状の光硬化性樹脂 を塗布または滴下し, (2)ナノオーダーの微細な凹凸を有す るモールドを押しつけて加圧する. (3)加圧した状態で光照 射して樹脂を硬化させた後, (4)樹脂からモールドを外し(離

\footnotetext{
* Sakai, Nobuji/Hirasawa, Tamano 東洋合成工業侏 新規事業開発部 千葉県印旛郡印旛村若萩 4-2-1（†270-1609） 2006. 12.15 受理
}

坂 井 信 支*・平 澤 玉 乃*

（1）初期状態

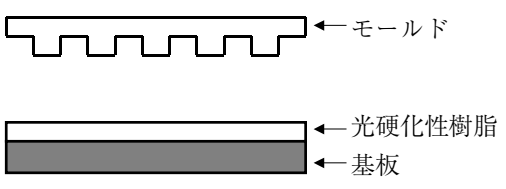

（2）プレス工程

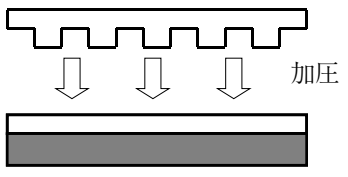

図 1 UV-NIL プロセス
（3）紫外線照射 光源; 超高圧水銀灯
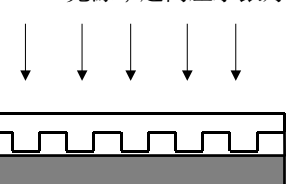

4）離型工程

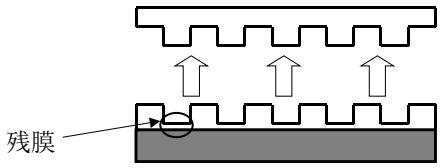

型)，樹脂に転写されたナノパターンを得る.

UV-NIL の場合は光照射を行う都合上，基板またはモー ルドの少なくとも一方が透明である必要があり, モールド 側から光照射する場合にはモールド材料には石英やサファ イア等のUV 光を透過する材質が用いられる.

\section{UV-NIL 用樹脂の材料選択}

UV-NIL に用いられる感光性樹脂はいわゆるネガ型と 呼ばれる光硬化性樹脂である．硬化システムの違いからラ ジカル重合型とカチオン重合型に大別される2,3). いずれ の樹脂でも UV-NIL に適用可能であるが, 硬化が速く材 料の選択範囲が広いラジカル重合型が一般に用いられてい る.ラジカル重合型樹脂は, 光重合開始剂と, ラジカル重 合可能なビニル基や（メタ）アクリル基を有するモノマー またはオリゴマーを含んだ組成物である．光照射すると， 光重合開始剤により発生したラジカルがモノマーまたはオ リゴマーのビニル基を攻撃して連鎖重合が進み，3 次元架 橋構造体を形成するものである. ラジカル重合型の UVNIL 用樹脂は，厳密には光の強度や膜厚によっても変わる が, 数十ナノ〜数百マイクロメートル程度の膜厚であれば 室温において数秒で硬化する.

なお，ラジカル重合型樹脂の問題点として一般に言われ ている酸素阻害 ${ }^{4}$ については, UV-NIL プロセスではあま り問題とされていない. UV-NIL では樹脂を型と基板で 挟んだ状態で露光するため，露光時に酸素が遮断されるか らである。 


\section{UV-NIL 用樹脂への要求特性}

樹脂の要求特性は(1)UV-NIL プロセス特性, (2)用途別 特性の二つに区分できる。(1)のプロセス特性としては，塗 布性, 基板密着性, 低粘性, 離型性, 速硬化性, 機械強度 などが要求される。UV-NILのプロセス特性は用途に関 わらず共通しており，これらの特性を有することを前提と して，その上で各用途別の樹脂特性を付与する必要がある. 市販されているUV-NIL用樹脂 PAK-01 はこれらの特 性をバランス良く有しているためプロセスマージンが広く, 国内外で UV-NIL の試験研究用に使用されている。一例 として PAK-01 の性状を表 1 に示す.

(2)の用途別の要求特性としては, 例えば光学部材につい ては屈折率や透過率等, エッチングレジストではエッチン グ耐性や残膜厚均一性などが挙げられる。これらの特性を 制御し, 諸特性のバランスを取ることが材料デザインの鍵 となる。

我々の場合は主として化学的なアプローチによる材料デ ザインや配合を行い，樹脂の特性を制御している。一例と して，ここでは塗布性の付与について記載する.

UV-NIL 用樹脂の塗布工程はスピンコート，バーコー 卜等による塗布法と，樹脂を基板にディスペンスする滴下 法の 2 種類に大別される. 滴下法では吐出の問題から樹脂 の粘性を下げる必要があり, 塗布法では樹脂が基板に均一 塗布可能であることが要求される. シリコンウェハーに塗 布した際，図 2 のように樹脂のハジキが発生する場合があ るが，樹脂の表面エネルギーや基板との濡れ性を考慮して 配合や組成を調整すると安定した塗布性が得られるように なる。

\section{UV-NIL 用樹脂の評価方法}

樹脂開発を行うためにはその性能を評価する技術が不可 欠である.しかし UV-NIL 用樹脂は通常のレジストや光 硬化性樹脂とは異なる特性を要求されるため, UV-NIL

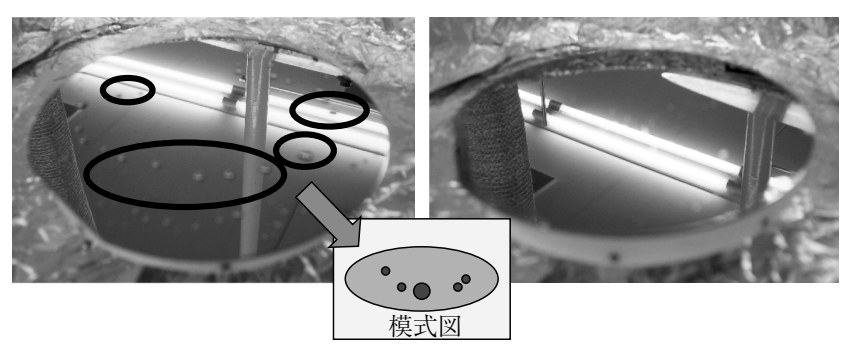

図 2 樹脂の塗布性（左図：エラー例, 中央図：左図の模 式図, 右図：塗布性改善例)

表 1 UV-NIL 材料「PAK-01」の主な性状・性能

\begin{tabular}{|c|c|}
\hline 外観 & 透明粘凋（ねんちょう）性液体 \\
\hline 粘度 & 約 $60 \mathrm{mPa} \cdot \mathrm{s}\left(25^{\circ} \mathrm{C}\right)$ \\
\hline 感光波長 & $400 \mathrm{~nm}$ 以下の紫外光（超高圧水銀灯） \\
\hline 解像性 & 30 nm（実績值） \\
\hline その他特性 & スピンコート適性, 離型性良好 \\
\hline
\end{tabular}

用樹脂開発と並行して新しい評価技術を合わせて開発する 必要がある。以下に, UV-NIL 用樹脂特有の特性評価方 法について記載する ${ }^{5}$.

\section{1 離型性と付着力測定}

UV-NIL では離型工程時にモールドに樹脂が付着し, パターンが剥がれるなどの不具合が生じやすい.これは樹 脂と基板の密着性が低いか, 樹脂とモールドの付着力が強 すぎる（離型性が低い）ことに起因する。

基板密着性については基板を表面処理するか, 基板密着 性を高める樹脂設計を行うことで解決できる，一方，離型 性については, あらかじめモールドに離型処理を行って離 型性を向上させるのが一般的である．モールド表面をフッ 素コーティングして撥水性を向上させる, 所謂テフロン コーティングと同様の原理を用いている.

離型処理には主にフッ素系のシランカップリング剤を用 い，石英表面に多数存在する $\mathrm{OH}$ 基と化学結合させる．離 型処理の効果については多数の文献があるので参照して頂 きたい( ${ }^{6), 7)}$.

UV-NIL 樹脂とモールドとの付着力を定量的に測定す ることは難しく, 現在でもほとんど研究例がないのが実情 である。ここでは図 3 に示すような引張試験機を用いた方 法を紹介する ${ }^{8)}$.

図 3 左図のように 2 枚のスライドガラスで光硬化性樹脂 を挟み, スペーサーで樹脂膜厚を規定した状態で UV 硬化 する. 硬化した基板を図 3 右図のような治具に装着し, 上 部から荷重を与えて, スライドガラスが剥離した時の変位 量（荷重）を検出する.この時の荷重と樹脂の接着面積か ら, 樹脂とモールドが接着する最大応力を求める. 最大応 力が小さい方が，樹脂のモールドへの付着力が小さいこと を意味する. 式は次のようになる.

\section{最大応力 $[\mathrm{MPa}]=$ 荷重 $[\mathrm{N}] /$ 接着面積 $\left[\mathrm{mm}^{2}\right]$}

UV-NIL 用樹脂を用いて付着力測定を行った結果の一 例を表 2 に示す. 離型剤として市販のオプッール DSX (ダ

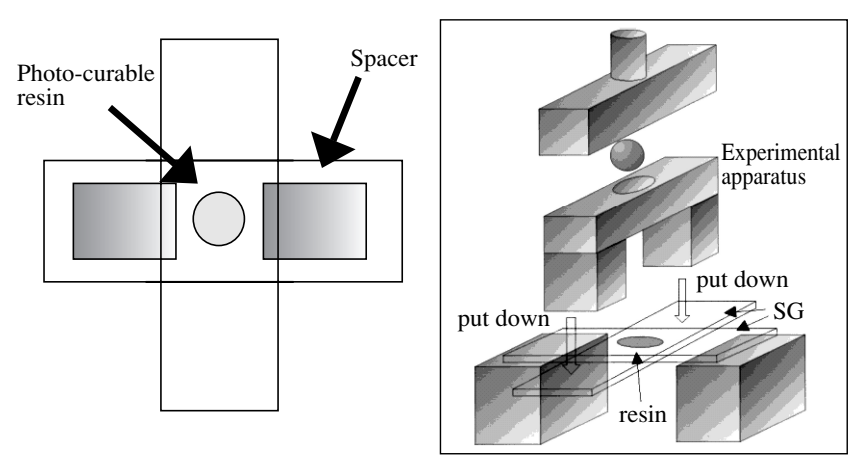

図 3 付着力測定方法

\section{表 2 付着力測定結果例}

\begin{tabular}{cccccc}
\hline $\begin{array}{c}\text { Release } \\
\text { agent }\end{array}$ & $\begin{array}{c}\text { Optool } \\
0.05 \%\end{array}$ & $\begin{array}{c}\text { Optool } \\
0.10 \%\end{array}$ & $\begin{array}{c}\text { Optool } \\
0.20\end{array}$ & EGC-1720 Not \\
\hline $\begin{array}{c}\text { Mean value } \\
(\mathrm{MPa})\end{array}$ & 0.053 & 0.053 & 0.06 & 0.055 & 0.83 \\
\hline
\end{tabular}


イキン工業製）と $\mathrm{EGC}-1720$ (住友 $3 \mathrm{M}$ 製）を使用した。 両者ともに浸漬法により離型処理を行った。オプッール DSX は，0.05〜0.2 重量\%の希釈溶液を調製して使用し ている.未処理の場合に比べ，大幅に付着力の低減が見ら れ, 離型処理により離型が容易になることが確認された.

\section{2 転写性}

UV-NIL 用樹脂の転写性は，モールド形状の忠実再現 性に置き換えて議論する. 光リソグラフィーと異なり, UV -NILではパターンの解像度やラインエッジラフネス （LER）が光源波長ではなくモールドの形状に依存する.

LER については走查型電子顕微鏡 $(\mathrm{SEM})$ や原子間力 顕微鏡（AFM）による測定例がある．産業総合技術研究 所と東京理科大学のグループは非常に低 LER のパターン 転写結果を報告している ${ }^{9)}$. Si の異方性ウエットエッチン グでラインアンドスペース $100 \mathrm{~nm}$ の低 LER モールドを 作製し，樹脂に転写したところ，モールドと転写パターン の LER 差は僅か $0.1 \mathrm{~nm}$ 程度であった。この LER 差は $\mathrm{SEM}$ 観察時の Ti 蒸着によるものであることが確認されて おり，UV-NILによる忠実な転写が実証されている。

転写性については，UV-NIL プロセスを用いて形成し たパターンを SEM 観察することにより確認する. 図 4 に UV-NIL 用樹脂を用いた $60 \mathrm{~nm}$ ラインの転写例を示す. またナノサイズに限らず，マイクロサイズのパターン転写 も可能である (図 5).

\section{3 機械特性}

UV-NIL 用樹脂の機械特性はナノインデンテーション 法により調べることができる. ナノインデンテーション法 とは, ダイヤモンド圧子に微小な荷重 $\mathrm{P}$ を加えて試料に 押し込みながら, 圧子の押込深さ h をナノメータの精度 で測定し, 得られた荷重一押込深さの関係から試料の機械 特性に関する情報を得ようとする材料評価法の一つである。 従来の硬さ試験(ビッカース法等)では困難であった薄膜の 硬さも測定できる点が特徴である．例えば PAK-01の硬 化物の場合, 基板の影響が少ないと考えられる押込深さ約

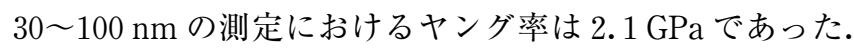
樹脂の機械特性と UV-NIL プロセス適性（離型時の欠 陷発生率など）との相関については今後調べる必要がある.

\section{4 硬化速度と反応率}

UV-NIL 用樹脂の硬化速度や反応率を調べる主な方法 としては，一般に UV 照射を行いながら FT-IR で反応性 基のピーク強度変化を追跡する方法, 及び UV 照射時の粘 弾性変化を測定する方法の 2 種類がある.

リソテックジャパン(株)と大阪府立大学のグループは, こ れらの方法を用いて UV-NIL 用樹脂の硬化速度を測定し ている ${ }^{10)}$. FT-IR 測定ではUV 照射を行いながら樹脂中の ビニル基の吸収強度変化をリアルタイム FT-IR で追跡し, その変化量から架橋率を求める方法である. 架橋率は, 露 光前の吸収強度を架橋率 $0 \%$, 大過剰に露光した場合を 100\% として算出する.

$\mathrm{UV}$ 照射量と樹脂の弾性率の相関は水晶振動子マイクロ バランス法 (QCM) により測定した. 水晶振動子表面に 物質を付着させ，その弾性率，密度等を変化させた場合に 振動子固有の周波数の変化が起こる. この周波数の変化量 から物質の重量変化や弾性率変化を求めることができる.

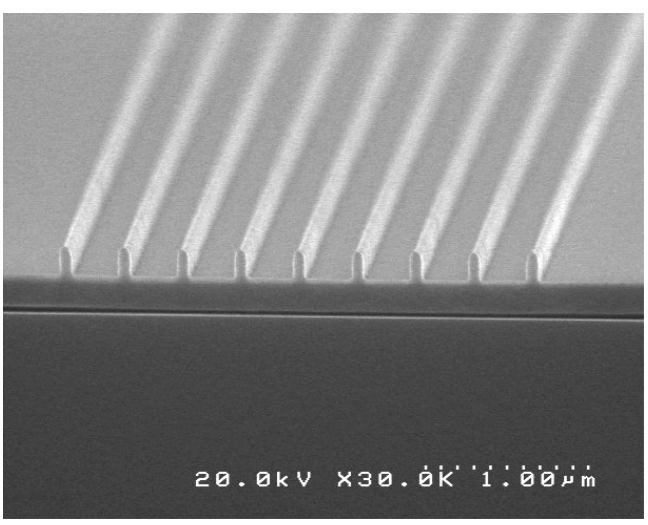

図 $460 \mathrm{~nm}$ ライン転写例

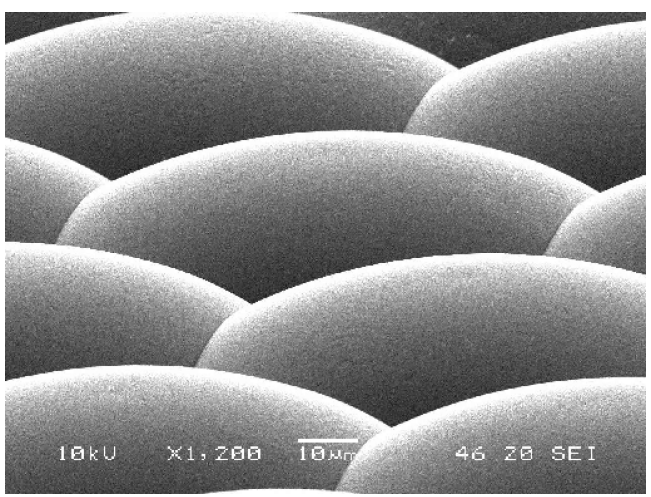

図 5 マイクロレンズパターン転写例

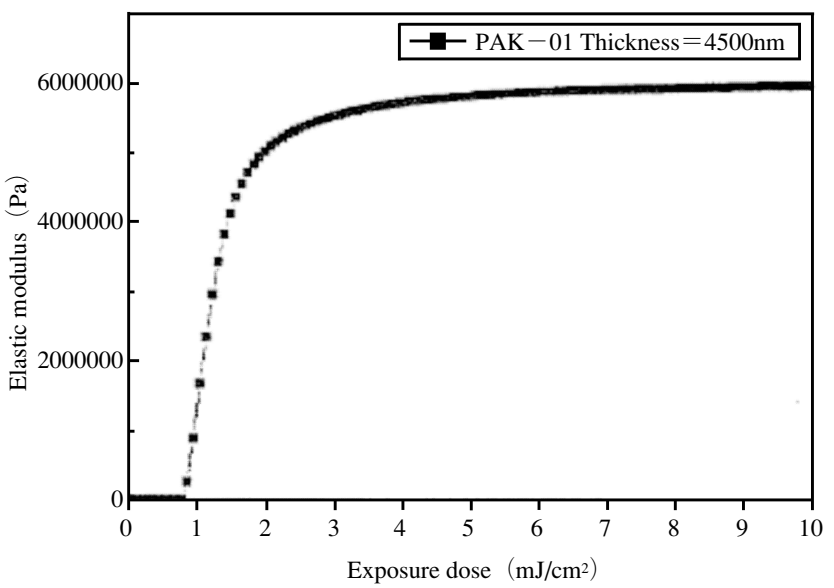

図 6 QCM 測定結果例

QCM 法を用いると, 薄膜状態での樹脂の弾性率の測定が 可能な点が有効である.

測定結果の例を図 6 に示す. UV 照射前の樹脂は粘性体 であるが, 露光量約 $0.8 \mathrm{~mJ} / \mathrm{cm}^{2}$ 付近から弾性率が急上昇 し，約 $10 \mathrm{~mJ} / \mathrm{cm}^{2}$ で弾性率は飽和に達している.

反応速度や反応率は使用するモノマーの構造や開始剤の 種類によって大きく変わる.これらの評価方法を用いるこ とで, 硬化速度が速く未反応モノマーが少ない樹脂開発が 可能になる. 

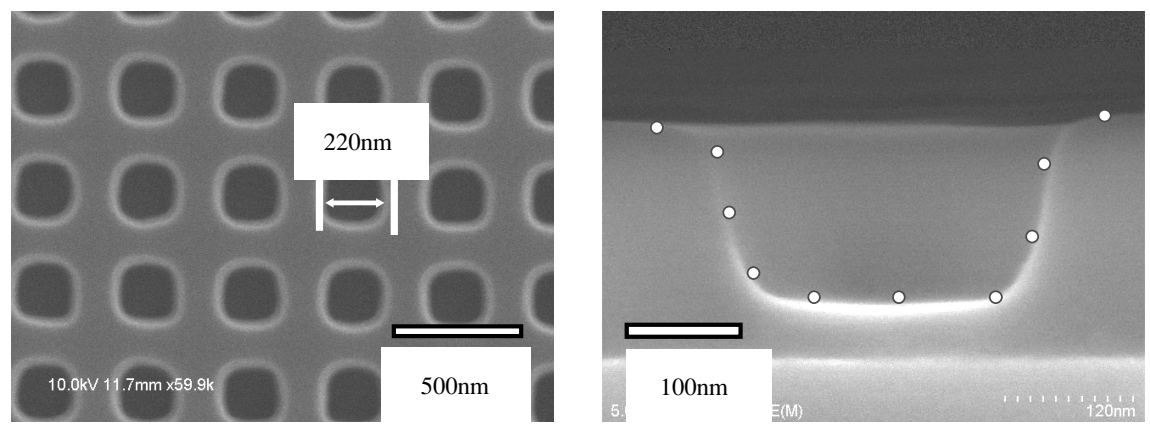

図 7 UV-NIL 法で作製した樹脂転写パターン

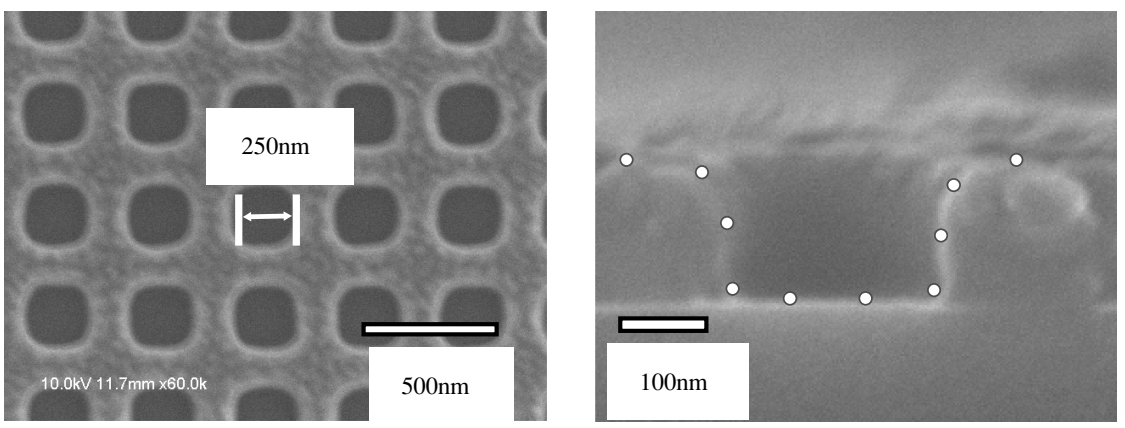

図 8 残膜除去後の樹脂転写パターン
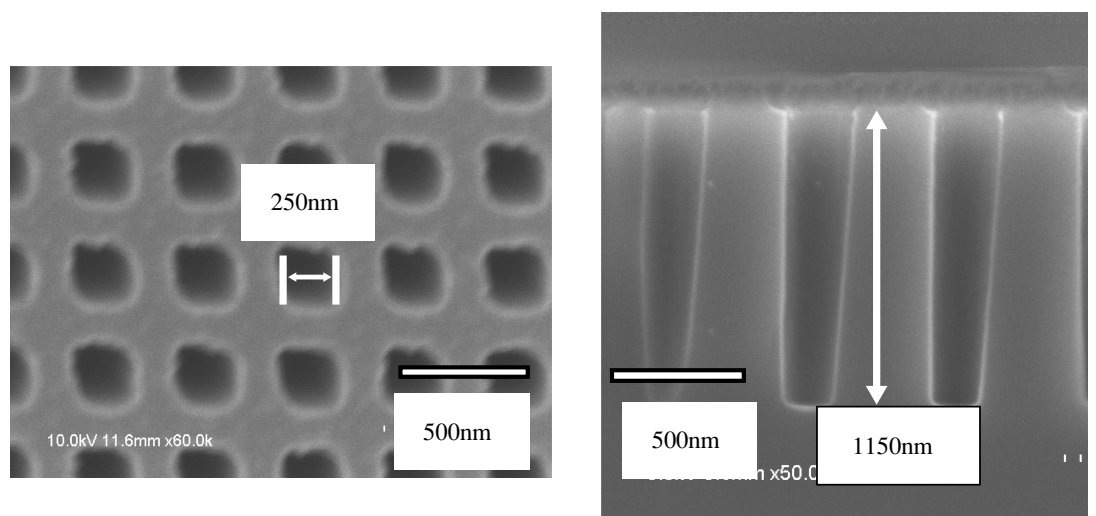

図 9 作製した高アスペクト比の Si 構造体

\section{UV-NIL プロセスを用いた微細加工例}

UV-NIL 用樹脂の用途は永久部材とプロセス材料とに 大別され，プロセス材料についてはさらに，半導体プロセ スに代表されるドライプロセス用，メッキ等のウェットプ ロセス用に分類される. 用途別の要求特性に応じて樹脂開 発を行い，微細加工を行った例を紹介する.

\section{1 ドライプロセス法}

ドライプロセス用の樹脂には耐エッチング性が要求され る. 早稲田大学水野助教授との共同研究により, UV-NIL を用いて $\mathrm{Si}$ の高アスペクト加工を行った例を紹介する ${ }^{11)}$. プロセスは以下の通りである.

シリコンウェハー上に光硬化性樹脂を塗布し, UV-NIL プロセスによって樹脂のナノパターンを得る. その後, 樹 脂パターンの残膜部分を $\mathrm{O}_{2}$ ドライエッチングで除去し,
残った樹脂パターンをマスクとしてフッ素系のガスでシリ コンをエッチングする.

まずUV-NILによりモールドと同サイズかつ低残膜の 樹脂ホールパターンを形成した(図 7). $\mathrm{O}_{2}$ エッチングでは 図 8 のように(若干表面の膜荒れとサイドエッチングが発 生したが)ホールパターン形状を維持したまま残膜を除去す ることが可能であった. 続くフッ素ガスエッチングにより,ア スペクト比4.6のSi構造体を作製することができた(図9).

\section{2 ウェットプロセス法}

ウェットプロセス用の樹脂には耐液性が要求される. 早 稲田大学水野助教授のグループと共同で, 電解メッキ法と UV-NIL を用いた金属ナノパターン形成を行った例を紹 介する ${ }^{12)}$ ・プロセスフローを図 10 に示す。

まず，通電層を形成した基板上に光硬化性樹脂を塗布し， UV-NIL プロセスによって樹脂のナノパターンを得る. 
その後, 樹脂パターンの残膜部分をドライエッチング法に よって除去し, 通電層を露出させる. 最後に電解メッキ法 を用いて金属ナノパターンを得る.

このプロセスを実施する上で，UV-NIL 用樹脂の特性 における 2 つ課題は (1)電解メッキに用いるメッキ液耐 性，(2)低残膜厚 である。

まず(1)について説明する．耐液性の低い樹脂を用いると メッキ液浸漬時に樹脂が膨潤し，パターンの寸法変化と基 板からの剥離が起こるという不具合がある。これに対し， 試作品はメッキ液に対し充分な耐性を示し, 上記不具合が 起こらないように改良した。

(2)については, 残膜厚を低減させるために塗布後の液膜 の厚みを薄くできるように改良した。 また，残膜厚を均一 化させるためにプレス時に面内に均一に荷重がかかるよう 工夫した装置を用いて転写した。これらにより，20 nm 程

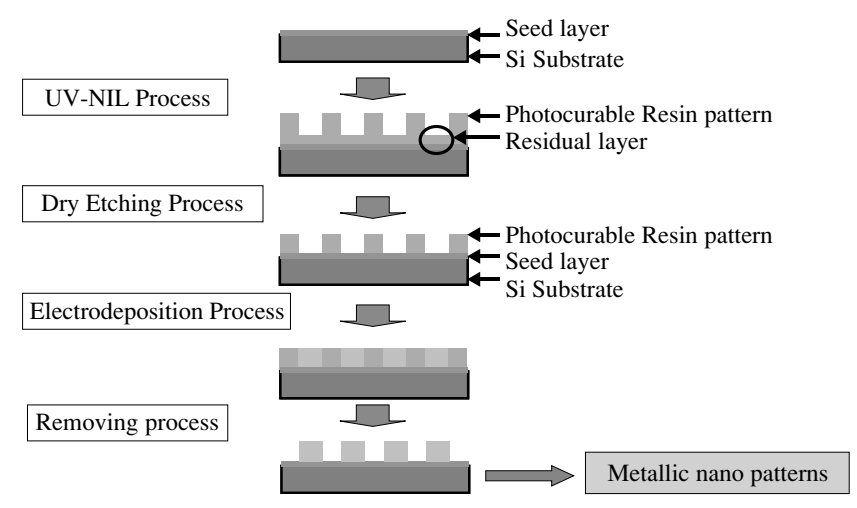

図 10 金属ナノパターン作製フロー
度の極めて薄い残膜を有するナノサイズのホール形状の樹 脂パターンが得られた (図 11 左). 残膜厚測定は AFM を 用いて行った。

次に残膜部分をドライエッチング法で除去し, 電解メッ キ法で樹脂のホール部からコバルト合金を析出させた. SEM 観察のためにアセトンに浸漬させ，樹脂を除去した 後の金属パターンの SEM 写真を示す（図 11 右). 他の手 法を用いると合金のナノパターン形成は複雑なプロセスあ るいは高価な装置が必要となるが, UV-NIL 技術を採用 すると比較的容易に作製することができる.

このような方法で作製した金属ナノパターンを用い，基 板を加工した例を図 12 に示す.ウェットプロセスで作製

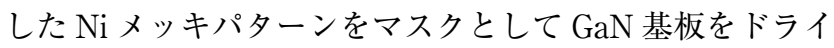
エッチングにより加工し，写真のような微細構造を形成し たものである ${ }^{13)}$. GaN のエッチングには非常に強い条件が 必要であり，有機レジストをマスクとして使用するのは難 しいため， $\mathrm{Ni}$ のようにエッチング耐性の高い材料で微細 パターンを形成できる点に優位性がある，加工した基板は LED の高効率化検討に用いられる.

\section{6.おわりに}

UV-NIL 用光硬化性樹脂の要求特性, 評価方法および 開発例を中心に記載した. 以上のように NIL 技術は急ピッ チで発展しているが，実用化における技術的課題も未だ残 されている．NIL 技術全般にかかる課題である，モールド 作製全般（作製技術，耐久性，作製コスト，修正技術）， 装置上の課題 (インプリント均一性, アラインメント精度), 検査技術，大面積化対応などを早期に克服して実用例を創 ることが，NIL 技術の産業化を加速すると考えている.
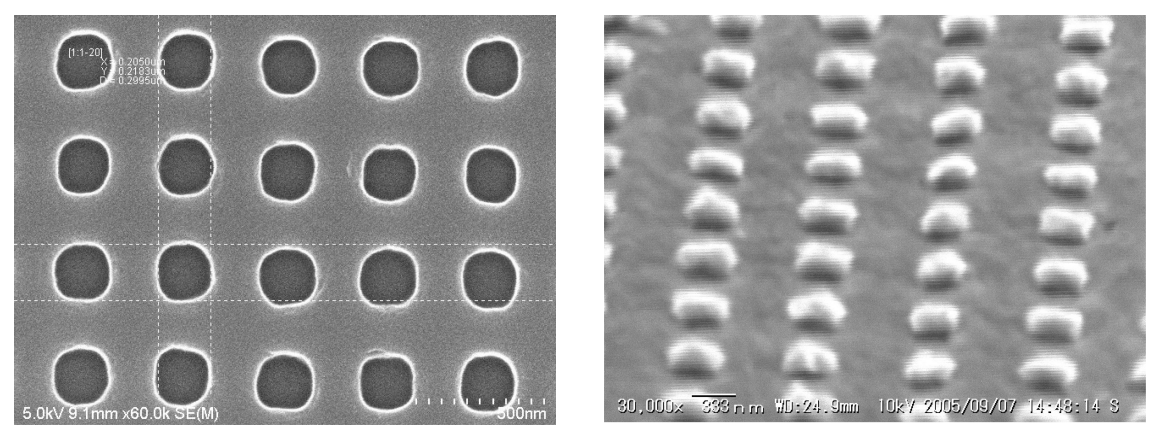

図 11 樹脂転写パターンと埋め込み後の金属パターン （左；200 nm ホールパターン, 右 ; $300 \mathrm{~nm}$ 金属パターン)

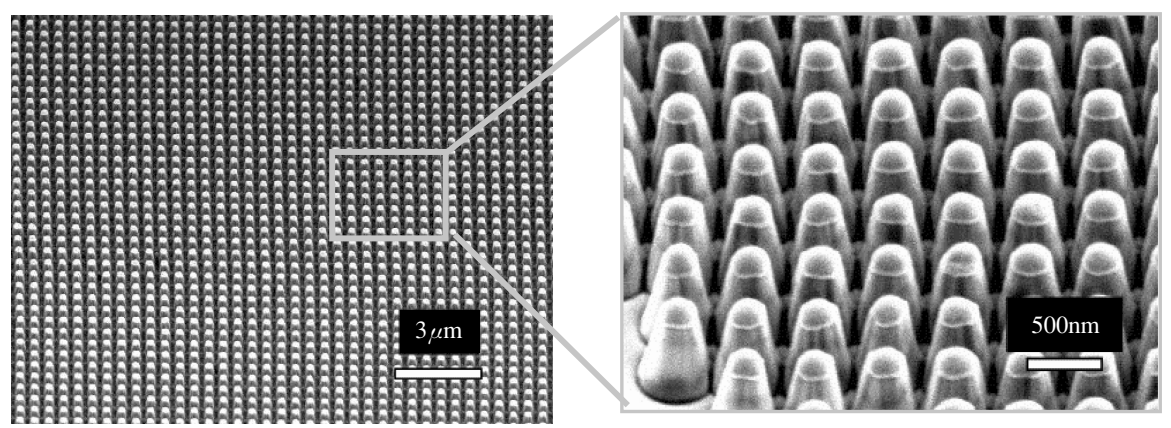

図 12 メッキで作製した金属パターンを用いた基板加工例 


\section{参 考 文 献}

1) Chou, S.Y., Krauss, P.R. and Renstrom, P.J. : Appl. Phys. Lett., 67, 3114(1995)

2 ) Crivello, J. V. : Proc. SPE Reg. Tech. Conf. on "Photopolymers, Principles, Process and Materials”, Nov. 8-10, Eiienville, N.Y., pp. 267 (1982)

3 ) Xu, F., Stacey, N., Watts, M., Truskett, V., McMackin, I., Choi, J., Schumaker, P., Thompson, E., Babbs, D., Sreenivasan, S.V., Willson, C.G. and Schumaker, N. : Proc. SPIE “Microlithography”, 5374, 232, February (2004)

4 ）“UV 硬化における硬化不良・阻害要因とその対策” 技術情報協会 (2003)

5 ) Sakai, N., Taniguchi, J., Kawaguchi, K., Ohtaguchi, M. and Hirasawa, T. : J. Photopolym. Sci. Technol., 18(4), 531 (2005)

6 ) Hirai, Y., Yoshida, S., Okamoto, A., Tanaka, Y., Endo, M., Irie, S., Nakagawa, H. and Sasago, M. : J. Photopolym. Sci. Technol., 14, 457 (2001)

7 ) Bailey, T., Choi, B.J., Colburn, M., Grot, A., Meissl, M., Shaya, S., Ekerdt, J.G., Sreenivasan, S.V. and Willson, C.G. : J. of Vac. Sci. \& Technol. B, 18(6), 3572(2000)

8 ) Taniguchi, J., Kawasaki, T., Tokano, Y., Kogo, Y., Miyamoto, I., Komuro, M., Hiroshima, H., Sakai, N. and
Tada, T. : Jpn. J. Appl. Phys., Part 1, 41, 4194(2002)

9 ) Kurashima, Y., Hiroshima, H., Komuro, M., Kim, S.H., Yamazaki, N., Taniguchi, J., Miyamoto, I,, Namatsu, H. and Matsui, S.: Jpn. J. Appl. Phys., 43(6 B), 4045 (2004)

10) Sekiguchi, A., Kono, Y. and Hirai, Y. : J. Photopolym. Sci. Technol., 4, 543 (2005)

11）大野浩志他：“UVインプリントを用いた高アスペク 卜比 $\mathrm{Si}$ ナノ構造体の作製”，マイクロマシン・センサ システム研究会，MSS-06-21，97-100（2006）

12) Ohtaguchi, M., Hirasawa, T., Osaki, T., Sakai, N., Edura, T., Mizuno, J., Saito, M., Shoji, S. and Homma, T. : "Fabrication of metallic nano patterns using a new photocurable resin durable for electrodeposition process", The 4 th International Nanoimprint and Nanoprint Technology Conference 2005, 20P-5-36, 100-101 (2005)

13) Ono, H., Ono, Y., Kasahara, K., Mizuno, J. and Shoji, S. : "Fabrication of High Light-Extraction Efficiency LED Using Nanostructures by UV Nanoimpr int Lithography and Electrodeposition”, the 2006 International Conference on SOLID STATE DEVICES AND MATERIALS (2006)

\section{賛助会員ならびに会員の皆様へ}

\section{「知りたい，見たい，訪ねたい一成形加工の元気な仲間一」の 訪問取材を希望される会社を募集中}

「成形加工」誌には，「知りたい，見たい，訪ねたい一成形加工の元気な仲間一」を掲載しています．本企画は， プラスチック成形加工に携わり，日本のものづくり産業の基盤を支えている活気ある企業を，本誌編集委員自ら が訪問取材して，会社概要および自慢の製品・技術を広く会員に紹介することを目的としたもので，詳細は以下 のとおりです.

1. 主として賛助会員あるいは正会員の所属する会社を，本誌編集委員が訪問し，新製品・新技術等を，実際 の製品を見て, あるいは現場見学を交えて取材し, 記事としてまとめ上げる. 会員による原稿執筆は一切 不要.

2 . 取材は, 2 時間程度.

3. 原稿は, 図表を含めて刷り上がり 2〜3ページとする.

4. 掲載料は無料.

この「知りたい, 見たい, 訪ねたい一成形加工の元気な仲間一」の訪問取材を是非ご検討下さい.

本企画は，年間 4 5 件を掲載する予定です．記事のスタイル，内容等につきましてはすでに掲載されている 幾つかの記事をご参照下さい.

$\lceil$ 成形加工」編集委員長 大嶋正裕 